\title{
IMPACT OF BIOFERTILIZERS AND CHEMICAL FERTILIZERS ON NODULATION, N UPTAKE AND GROWTH OF SOYBEAN (Glycine max L.)
}

\author{
${ }^{1}$ Betty Natalie Fitriatin, ${ }^{2}$ Rahadian Nur Prathama, ${ }^{1}$ Reginawanti Hindersah \\ ${ }^{1}$ Soil Science Department, Faculty of Agriculture, Universitas Padjadjaran, Indonesia \\ ${ }^{2}$ Graduated from Agrotechnology, Faculty of Agriculture, Universitas Padjadjaran, Indonesia
}

DOI: 10.46609/IJAER.2020.v06i01.003 URL: https://doi.org/10.46609/IJAER.2020.v06i01.003

\begin{abstract}
Soybean is one of the important food crops as a source of protein. Nowadays, soybean production should be increased due to higher demand in certain region in Indonesia. Biofertilizer inoculation combine with chemical fertilizer is suggested to increase the soil fertility to support soybean cultivation and decrease the use of chemical fertilizer. The pot experiment was conducted to get the information concerning nodulation, nitrogen uptake and growth of soybeans (Glycine max L.) after biofertilizer and Nitrogen $(\mathrm{N})$, Phosphorous $(\mathrm{P})$ as well as potassium $(\mathrm{K})$ single fertilizer application. The experiment was set up in a randomized block design with seven treatment and four replications. The treatments consisted of two doses of biofertilizer ( $3 \mathrm{~L} \mathrm{ha}^{-1}$ and $5 \mathrm{~L} \mathrm{ha}^{-1}$ ) combined with three doses of $\mathrm{N}, \mathrm{P}, \mathrm{K}$ fertilizer $(50 \%, 75 \%$ and $100 \%$ recommended dosage). The pot control received no biofertilizer. Consortium biofertilizers contained N-fixing bacteria (Azotobacter chroococcum, A. vinelandii, Azospirillum sp. and endophytic Acinetobacter sp.) and phosphate solubilizing microbes (Pseudomonas cepaceae and Penicillium sp.). The results of experiment showed that the application of biofertilizer $5 \mathrm{~L} \mathrm{ha}^{-1}$ combined with $75 \%$ chemical fertilizer increased the nodules number, nitrogen uptake and dry weight of plant at the end of vegetative stage. This study suggested that biofertilizer might be used to increase growth of soybean and chemical fertilizer efficiency.
\end{abstract}

Keywords: Biofertilizer, Inceptisols, N-uptake, Nodule, Soybean (Glycine max L.).

\section{INTRODUCTION}

Soybean is known as a plant that requires large amounts of nitrogen. If these needs by inorganic $\mathrm{N}$ fertilizer, it requires a large cost and long-term use has a negative impact on the environment. 
International Journal of Agriculture and Environmental Research

ISSN: 2455-6939

Volume: 06, Issue: 01 "January-February 2020"

Soybean plants to get $\mathrm{N}$ through symbiosis with $\mathrm{N}$-fixing bacteria called rhizobia. Therefore it can be overcome with the application of biological fertilizers that contain bacteria that can fix $\mathrm{N}_{2}$ from the air (Htwe et al., 2019). Biofertilizers are inoculants made from active living organisms in liquid or solid forms that have the ability to mobilize, facilitate and increase the availability of nutrients not available into available forms through biological processes.

One way to increase soybean production is to improve the root area. Rooting areas are important to note because roots have a major role in transporting water and nutrients to the leaves which are related to plant survival. In addition, good root development will also support the process of nitrogenase, absorption of other nutrients and adaptation and acclimatization of plants more quickly (Kleinert et al. 2018). Soybean roots will symbiosis with Rhizobium bacteria to form root nodules. Nodule development in legumes directly affects nitrogen fixation. The effects of exogenous factors affecting nodulation in soybeans as well as in other larger legumes (Choudhury et al., 2019). N-fixing bacteria increased significantly plant growth, nodulation, nitrogen fixation, NPK uptake, and yield of mung beans and soybeans (Htwe et al., 2019). Phosphate solubilizing bacteria increase soil P-available due to organic acids and phosphatases produced by PSB that can release fixed P and P mineralization (Kalayu, 2019).

The use of a biofertilizer can help the growth of soybean plants and increase crop yields because it can fixed free nitrogen from the air, help provide phosphate for plants (Fitriatin et al. 2014) and can produce growth-stimulating hormones such as IAA, cytokinins, gibberellins, auxins (Olanrewaju et al., 2017) and exopolysaccharide (Hindersah et al., 2017). The added consortium of biofertilizers containing phosphate solubilizing bacteria (PSB) such as Pseudomonas cepaceae; phosphate solubiizing fungi (PSF) such as Penicillium sp; and nitrogen-fixing bacteria such as Azospirillum, Azotobacter vinelandii, and Azotobacter chroococcum; and endopytic bacteria (Acinetobacter). These microbes are used for the consortium of biofertilizers because it can provide benefits to plants. Some research results showed that consortium isolates are better than single isolates. According to Olumwambe and Kofoworola (2016) that tomato seed treated with the consortium of several effective strains for growth enhancement performed better than their individual culture.

Utilization of the consortium of biofertilizers on soybean is expected to improve plant growth and productivity and reduce chemical residues caused by inorganic fertilization. Therefore, research is needed the application of biofertilizers to find out treatment gives the best response to nodulation, nitrogen uptake and growth of soybean.

\section{MATERIALS AND METHODS}


International Journal of Agriculture and Environmental Research

ISSN: 2455-6939

Volume: 06, Issue: 01 "January-February 2020"

The pot experiment was conducted in field station, Faculty of Agriculture, Universitas Padjadjaran, West Java, Indonesia. The experimental site was located in the tropics at $756 \mathrm{~m}$ above the sea lavel. The soybean cv Anjasmoro were sown in soil of Inceptisols order collected from Jatinangor District, West Java, Indonesia (clay texture; pH 5,58; C-org 1,89\%; N 0,24\%; $\mathrm{P}_{2} \mathrm{O}_{5}$ Bray 30,25 ppm; CEC 20,76 cmol. $\left.\mathrm{kg}^{-1}\right)$. Consortium biofertilizer which contained $\mathrm{N}$-fixing bacteria Azotobacter chroococcum, A. vinelandii,Azospirillum sp, and Acinetobacter sp., as well as Phosphate solubilizing microbes Pseudomonas cepaceae and Penicillium sp. has been developed by Laboratory of Soil Biology in said Institution. The density of bacteria and fungi in

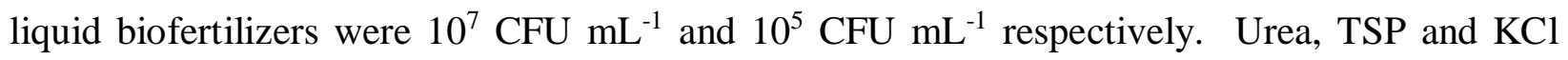
single Chemical fertilizers were produced by national fertilizer industry. The recommended dosage of said fertilizer for soybean cultivation in Indonesia were Urea $(46 \% \mathrm{~N}) 50 \mathrm{~kg} \mathrm{ha}^{-1}$, triple super phosphate $\left(36 \% \mathrm{P}_{2} \mathrm{O}_{5}\right) 100 \mathrm{~kg} \mathrm{ha}^{-1}, \mathrm{KCl}\left(60 \% \mathrm{~K}_{2} \mathrm{O}\right) 100 \mathrm{~kg} \mathrm{ha}^{-1}$ and cow manure $2 \mathrm{t}$ $\mathrm{ha}^{-1}$. The compost of cow manure was prepared by Faculty of Husbandry Universitas Padjadjaran; manure was neutral in acidity $7.50, \mathrm{~N} \mathrm{0.94 \% ,} \mathrm{P}_{2} \mathrm{O}_{5} 0,37 \%$ and $\mathrm{K}_{2} \mathrm{O} 0.29 \%$ and contained $25.38 \%$ water.

The experiment arranged in a randomized block design with seven combinations and four replications. The treatments consisted of two doses of biofertilizer/BF $\left(0,3 \mathrm{~L} \mathrm{ha}^{-1}\right.$ and $\left.5 \mathrm{~L} \mathrm{ha}^{-1}\right)$, combined with three recommended doses of chemical fertilizer/CF (50\%, 75\% and 100\%). All the treatments were replicated three times. $\mathrm{N}$ uptake, nodulation and growth of Soybean (plant height, shoot and root dry weight) were measured at the end of vegetative period.

Soil was collected from top soil prior to separating plant debris from the bulk soil. A total of 15 $\mathrm{kg}$ soil was placed in polybag, mixed with $15 \mathrm{~g}$ organic matter (equal to $2 \mathrm{t} \mathrm{ha}^{-1}$ ) and incubated for 5 days in field without shade.

Soybean seeds were inoculated with liquid Bradyrhizobium inoculant mixed with gum arabic; two soybean seeds were placed in seperated hole, and covered with soil. Biofertilizer was diluted $5 \%$ by using ground water and inoculated $20 \mathrm{~mL}$ per polybag by pouring around 5-days old transplant. Chemical fertilizers were applied twice at 7 days and 14 days after planting. The experimental units were maintain for 42 days after planting when the plants were at the end of vegetative period.

At the end of experiment, shoots were separated from roots and heated in the oven of $70^{\circ} \mathrm{C}$ prior to nitrogen content analysis and dry weight measurement. Roots were washing gently using tap water; all the nodule were collected and dried using filter paper and weighed. Nitrogen uptake were calculted based on Nitrogen content which determined by Kjeldahl Method. All the data were subjected to variance analysis using $\mathrm{F}$ test (p 0.05\%). If the effect of treatment on said plant parameter was significant then Duncan's Multiple Range Test (p 0.05\%) was conducted. 


\section{RESULTS AND DISCUSSIONS}

\section{Nodule number}

The effect of biofertilizers and chemical fertilizers increase nodule number. Figure 1 shows that application of $5 \mathrm{~L} \mathrm{ha}^{-1}$ biofertilizers $+75 \%$ dosage of chemical fertilizers are better treatment to increase the nodule number. This is supported that Azotobacter in the biofertilizers able to produce exopolysaccharides needed for Rhizobium sp. in inducing the formation of nodules (Gauri et al. 2012). This exopolysaccharide is used as a signal by the bacterium Rhizobium so that it can stick to the ends of the roots of soybean hair and then infect the soybean plant root cells (Ibanez et al. 2017).

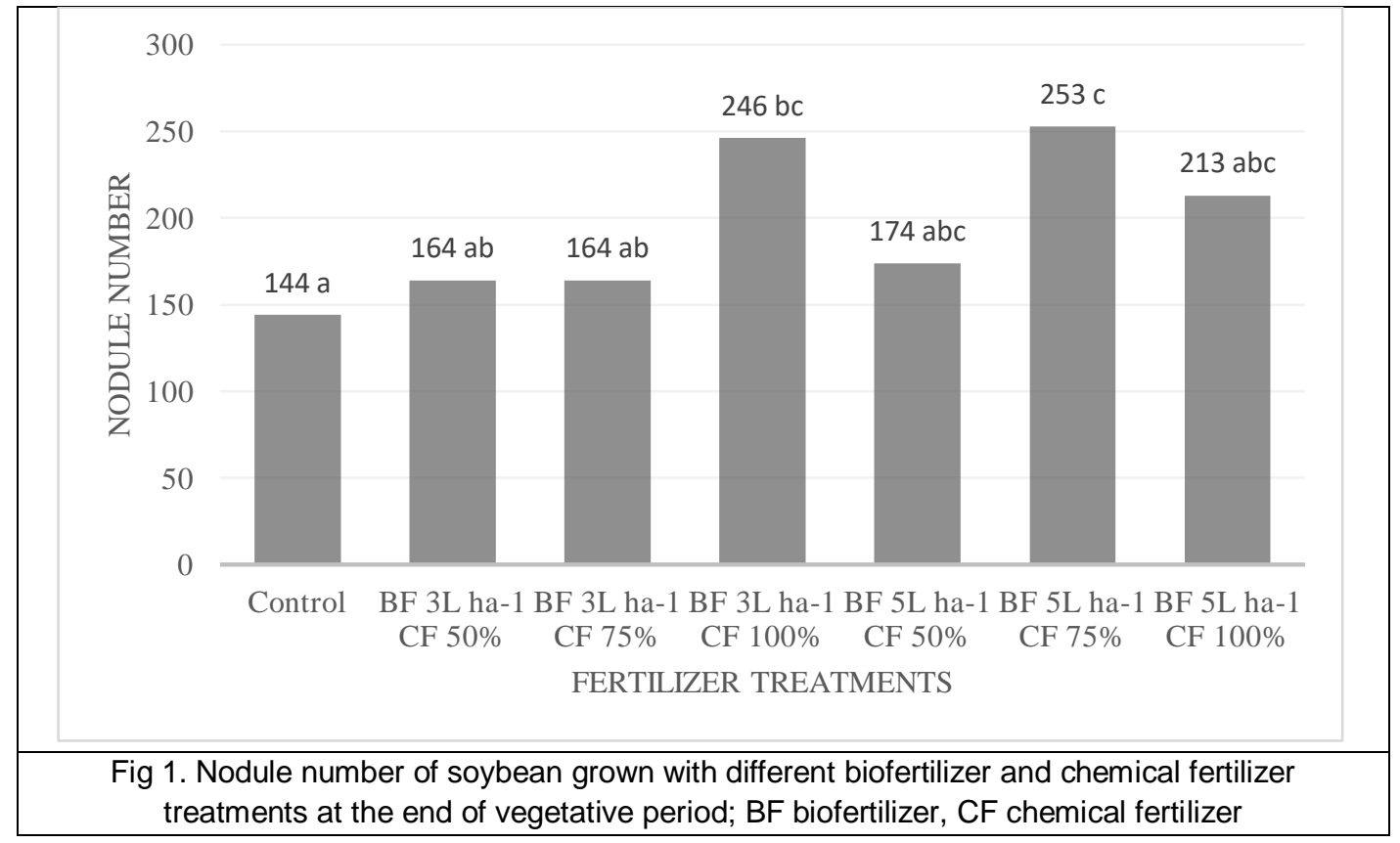

Treatment of $100 \%$ dosage of chemical fertilizer (control) had roots with the lowest nodule number. This is caused by the treatment was not combined with biofertilizers so that the infection of Rhizobium sp. into the root is not as effective as other treatments. Bekere et al. (2013) reported that higher amount of inorganic fertilizer inhibits the nitrogen fixation in early stage of plant.

Phosphate solubilizing microorganisms in the consortium of biofertilizers affect the formation of nodules because it can increase phosphate availability (Zaidi et al. 2010). This is because phosphate is one of the energy sources by plants to compile adenosine triphosphate (ATP) where ATP is used as an energy source by Rhizobium sp. (Malhotra et al. 2018). 
International Journal of Agriculture and Environmental Research

ISSN: 2455-6939

Volume: 06, Issue: 01 "January-February 2020"

The addition of sufficient chemical fertilizer also plays a role in increasing the effectiveness of Rhizobium sp. in the formation of nodules. Application of sufficient amount of $\mathrm{N}$ fertilizer stimulate growth of root hair more quickly and cause $\mathrm{N}$ inhibition by Rhizobium sp. to the maximum. $\mathrm{P}$ fertilizer plays an important role in the formation of root nodules because it helps the synthesis of ATP and nicotinamide adenine dinucleotide phosphate (NADPH) as a source of energy for microbes (Malhotra et al. 2018). K Fertilizer plays a role in increasing the translocation of photosynthesis to the roots used by Rhizobium sp.

\section{Plant $N$ uptake}

Table 1 shows that the combination of biofertilizers and chemical fertilizers increase the $\mathrm{N}$ uptake of soybean significantly. This shows that $\mathrm{N}$-fixing bacteria contained in biofertilizers increased soil $\mathrm{N}$ so that $\mathrm{N}$ absorbed by plants increases. The treatment of $5 \mathrm{~L} \mathrm{ha}^{-1}$ biofertilizer and $75 \%$ dosage of chemical fertilizer are able to absorb $\mathrm{N}$ higher than other treatments. Increased $\mathrm{N}$ uptake of soybean plants is thought to be due to an increase in the nodules number caused by $\mathrm{N}$ fixation activity by Azotobacter sp., Acinetobacter sp., and Azospirillum sp. contained in the consortium's biological fertilizer. According to Ohyama et al. (2017) which states that soybean plants that have enough $\mathrm{N}$ due to $\mathrm{N}_{2}$ fixation by effective nodules can increase nutrient uptake and reduce the dose of chemical fertilizer so that plants will grow better. With the increase in the number of root nodules, the absorption of nitrogen by plants will also increase.

Table 1: Plant N-uptake at the end of vegetative period

\begin{tabular}{|c|c|}
\hline Treatments & $\mathrm{N}$ uptake $\mathrm{g}$ plant ${ }^{-1}$ \\
\hline Control (CF 100\%) & $0.17 \mathrm{a}^{*}$ \\
\hline $\mathrm{BF} 3 \mathrm{~L} \mathrm{ha}{ }^{-1}+\mathrm{CF} 50 \%$ & $0.27 \mathrm{ab}$ \\
\hline $\mathrm{BF} 3 \mathrm{~L} \mathrm{ha}{ }^{-1}+\mathrm{CF} 75 \%$ & $0.28 \mathrm{ab}$ \\
\hline $\mathrm{BF} 3 \mathrm{~L} \mathrm{ha}^{-1}+\mathrm{CF} 100 \%$ & $0.37 \mathrm{bc}$ \\
\hline $\mathrm{BF} 5 \mathrm{~L} \mathrm{ha}^{-1}+\mathrm{CF} 50 \%$ & $0.30 \mathrm{~b}$ \\
\hline $\mathrm{BF} 5 \mathrm{~L} \mathrm{ha}^{-1}+\mathrm{CF} 75 \%$ & $0.42 \mathrm{c}$ \\
\hline BF $5 \mathrm{~L} \mathrm{ha}^{-1}+\mathrm{CF} 100 \%$ & $0.31 \mathrm{bc}$ \\
\hline
\end{tabular}

Increasing of chemical fertilizers did not improve $\mathrm{N}$-uptake with application biofertilizers $5 \mathrm{~L} \mathrm{ha}^{-}$ ${ }^{1}$. However, application $100 \%$ dosage of chemical fertilizers were too high, and biofertilizers could have partially replaced the NPK fertilizer inputs. According to Solanki et al. (2018) that nutrient uptake decreases with increasing NPK fertilizer dosage. 


\section{Growth of soybean}

The application of biofertilizers and chemical fertilizers did not affect significantly on plant height at the end of vegetative period. This was thought to be due to humidity reaching $92 \%$ during the planting period making soybean growth less than optimal. According to An et al. (2001), that humidity influence to growth of soybean. The optimal air humidity for soybean growth is $75-90 \%$.

Table 2: Growth of soybean (plant height, shoot dry weight and root dry weight) at the end of vegetative period.

\begin{tabular}{|c|c|c|c|}
\hline Treatments & Plant height $(\mathrm{cm})$ & $\begin{array}{c}\text { Shoot dry weight } \\
\text { (g) }\end{array}$ & $\begin{array}{l}\text { Root dry weight } \\
\text { (g) }\end{array}$ \\
\hline Control (CF 100\%) & $28,6 \mathrm{a}$ & $5,31 \quad \mathrm{a}$ & $1,69 \mathrm{a}$ \\
\hline $\mathrm{BF} 3 \mathrm{~L} \mathrm{ha}^{-1}+\mathrm{CF} 50 \%$ & $31,1 \mathrm{a}$ & $7,68 \mathrm{ab}$ & $2,52 \mathrm{ab}$ \\
\hline BF 3L ha-1 + CF 75\% & $32,9 \mathrm{a}$ & 8,69 bcd & $2,39 \mathrm{ab}$ \\
\hline BF $3 \mathrm{~L} \mathrm{ha}^{-1}+\mathrm{CF} 100 \%$ & $34,7 \mathrm{a}$ & $11,10 \mathrm{~cd}$ & $3,47 \mathrm{~cd}$ \\
\hline $\mathrm{BF} 5 \mathrm{~L} \mathrm{ha}^{-1}+\mathrm{CF} 50 \%$ & $31,6 \mathrm{a}$ & $8,31 \mathrm{bc}$ & $2,54 \mathrm{ab}$ \\
\hline BF 5L ha-1 + CF 75\% & $35,3 \mathrm{a}$ & $11,38 \mathrm{~d}$ & $3,61 \mathrm{~d}$ \\
\hline BF $5 \mathrm{~L} \mathrm{ha}^{-1}+\mathrm{CF} 100 \%$ & $34,5 \mathrm{a}$ & 8,95 bcd & $2,72 b c$ \\
\hline
\end{tabular}

*Note: Numerics followed by the same letters were non-significant on $95 \%$ Duncan's New Multiple Range Test

Table 2 shows that the plant height in the treatment of $100 \%$ dosage of chemical fertilizers were $28.6 \mathrm{~cm}$ while $5 \mathrm{~L} \mathrm{ha}^{-1}$ of biofertizer and $75 \%$ dosage of chemical fertilizers was $35.31 \mathrm{~cm}$. This indicates that the application of biofertilizers has the potential to increase plant height of soybean. Azotobacter sp., Azospirillum sp., and Acinetobacter sp. in biofertilizers can produce growth regulators such as IAA, cytokinins and gibberellins which promote cell elongation and division (Olanrewaju et al. 2017). Pseudomonas cepaceae and Penicillium sp. which is also present in biofertilizers dissolve $\mathrm{P}$ into available so that it can stimulate cell division and cell differentiation which can increase plant height. According to Fitriatin et al. (2018), that biofertilizers contain Pseudomonas cepaceae and Penicillium sp. as phosphate solubilizing microorganisms increase plant height.

The results of experiment showed that the combination of biofertilizers and chemical fertilizers significantly affected on the plant dry weight. Table 2 shows that the application of biofertilizers and chemical fertilizers increased the shoot and root dry weight. The application $5 \mathrm{~L} \mathrm{ha}^{-1}$ of biofertilizer and $75 \%$ dosage of chemical fertilizers increased shoot dry weight up to $114,31 \%$ 
compare with control (Fig.2). This increase is higher than other treatments. The increase in plant growth due to this treatment is in line with the data on plant $\mathrm{N}$ uptake as has been shown in Table 1. The same effect of this treatment on the increase to root dry weight reached $81.18 \%$ was higher than other treatments.

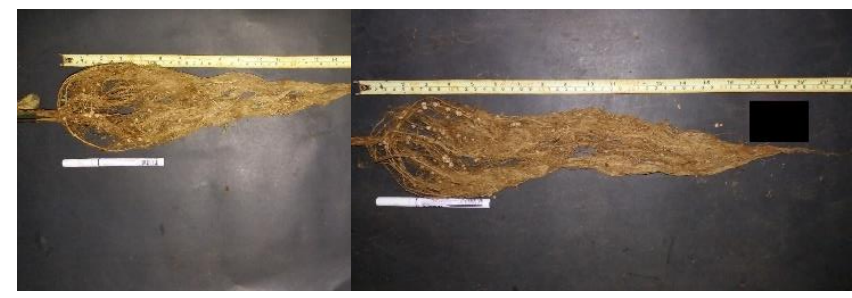

Control

Biofert $5 \mathrm{~L} \mathrm{ha}^{-1}+$ chemical fertilizers $75 \%$

Fig. 2: Growth of root at the end of vegetative period (comparison of control with BF $5 \mathrm{~L} \mathrm{ha} \mathbf{a}^{-1}+\mathrm{CF} 75 \%$ )

\section{CONCLUSIONS}

This study indicate that biofertilizers consortium of N-fixing bacteria (Azotobacter chroococcum, Azotobacter vinelandii, Azospirillum), phosphate solubilizing microbes (Pseudomonas cepaceae, Penicillium sp.) and endopytic bacteria (Acinetobacter sp.) increased nodulation, plant $\mathrm{N}$ uptake and growth of soybean. The application of biofertilizers $5 \mathrm{~L} \mathrm{ha}^{-1}$ and $75 \% \mathrm{~N}, \mathrm{P}, \mathrm{K}$ fertilizer increased the nitrogen uptake, nodules number, dry weight of plant. This study implied that biofertilizer might be used to increase growth of soybean and NPK fertilizer efficiency.

\section{ACKNOWLEDGMENTS}

We are grateful to assistant of Soil Biology Laboratory Faculty of Agriculture, Universitas Padjadjaran for supporting us during experiment. We are thankful National Fertilizer Company, PT. Pupuk Kujang for collaborating on the development of biofertilizers.

\section{REFERENCES}

An, P., S. Inanaga, U. Kafkafi, A. Lux and Y. Sugimoto. 2001. Different Effect of Humidity on Growth and Salt Tolerance of Two Soybean Cultivars. Biologia Plantarum. 44, Issue 3, pp 405-410| 
International Journal of Agriculture and Environmental Research

ISSN: 2455-6939

Volume: 06, Issue: 01 "January-February 2020"

Bekere W, T. Kebede, and J. Dawud. 2013. Growth and nodulation response of soybean (Glycine max L.) to lime, Bradyrhizobium japonicum and nitrogen fertilizer in acid soil at Melko, south western Ethiopia. Int J Soil Sci 8:25-31.

Choudhury, S.R., S.M. Johns and S. Pandey. 2019. A convenient, soil-free method for the production of root nodules in soybean to study the effects of exogenous additives. Plant Direct. ;1-11.

Fitriatin, B.N. , A. Yuniarti, and T. Turmuktini. 2014. The effect of phosphate solubilizing microbe producing growth regulators on soil phosphate, growth and yield of maize and fertilizer efficiency on Ultisol. Eurasian Journal of Soil Science Vol 3 pp. 104 -107.

Fitriatin, B.N., P. Tamara, O. Mulyani, E.T. Sofyan, A.Yuniarti and T. Turmuktini. 2018. Influence of biofertilizer and humic acid on NPK content and yield of rice (Oryza sativa L.). International Journal of Agriculture, Environment and Bioresearch. 3: 20-27

Gauri, S.S., S.M. Mandal and B. R. Pati. 2012. Impact of Azotobacter exopolysaccharides on sustainable agriculture. Appl Microbiol Biotechnol 95:331-338.

Hindersah, R., O. Mulyani and R. Osok. 2017. Proliferation and exopolysaccharide production of Azotobacter in the presence of mercury. Biodiversity Journal, 8 (1): 21-26

Htwe, A.Z., S.M. Moh, K.M.Soe, K.Moe and T. Yamakawa. 2019. Effects of biofertilizer produced from Bradyrhizobium and Streptomyces griseoflavus on plant growth, nodulation, nitrogen fixation, nutrient uptake, and seed yield of mung bean, cowpea, and soybean. Agronomy ,9 (77): 1-15

Ibáñez, F., L.Wall and A. Fabra. 2017. Starting points in plant-bacteria nitrogen-fixing symbioses: intercellular invasion of the roots. Journal of Experimental Botany, 68 (8): 1905-1918

Kalayu, G. 2019. Phosphate solubilizing microorganisms: Promising approach as biofertilizers. International Journal of Agronomy . https://doi.org/10.1155/2019/4917256

Kleinert, A., V. A. Benedito, R. J. L. Morcillo, J. Dames, P. Cornejo-Rivas, A. Zuniga-Feest, M. Delgado, and G. Muñoz. 2018. Morphological and Symbiotic Root Modifications for Mineral Acquisition from Nutrient-Poor Soils. Chapter 4 In Book : Root Biology. Springer International Publishing AG. Pp. 85-142. https://doi.org/10.1007/978-3-319$\underline{75910-4 \quad 4}$ 
Malhotra H., Vandana, S. Sharma, and R. Pandey. 2018. Phosphorus Nutrition: Plant Growth in Response to Deficiency and Excess. Chapter 7 In book : Plant Nutrients and Abiotic Stress Tolerance. DOI. 10.1007/978-981-10-9044-8_7. Pp. 171-190

Ohyama, T., K. Tewari, S. Ishikawa, K.Tanaka, S. Kamiyama, Y. Ono, S. Hatano, N. Ohtake, K. Sueyoshi, H. Hasegawa, T. Sato, S. Tanabata, Y. Nagumo, Y.Fujita and Y. Takahashi. 2017. Role of Nitrogen on Growth and Seed Yield of Soybean and a New Fertilization Technique to Promote Nitrogen Fixation and Seed Yield. Chapter 9 In Book : Soybean The Basis of Yield, Biomass and Productivity. http://dx.doi.org/10.5772/66743. pp 154185

Olanrewaju, O.S., B.R. Glick, and O.O Babalola. 2017. Mechanisms of action of plant growth promoting bacteria. World J Microbiol Biotechnol 33:197. DOI 10.1007/s11274-0172364-9.

Olumwambe, T.M. and A.A. Kofoworola,. 2016. Comparison of single culture and the consortium of growth-promoting rhizobacteria from three tomato (Lycopersicon esculentum Mill) varieties. Advances in Plants \& Agriculture Research. 5 (1):448-455

Solanki, A.C., M.K. Solanki, A.Nagwanshi, A.K. Dwivedi1 and B.S. Dwived. 2018. Nutrient Uptake and Grain Yield Enhancement of Soybean by Integrated Application of Farmyard Manure and NPK. International Journal of Current Microbiology and Applied Sciences. 7 (09): 1039-1102

Zaidi A., M. Ahemad, M. Oves, E. Ahmad,and M.S. Khan. 2010. Role of Phosphate-Solubilizing Bacteria in Legume Improvement. Chapter 11 In book: Microbes for Legume Improvement. DOI. 10.1007/978-3-211-99753-6_11. Pp. 273-292 